Contributions to the Yournal are welcomed. They may be submitted in either English or French. They should not exceed about 6000 words (excluding footnotes), except with the prior approval of the Editors. A summary of the contents of the article, not exceeding about 300 words in length, should be attached on a separate sheet. Contributors are asked to observe closely the conventions listed in the Notes for Contributors, Vol. XV, pp. I73-4. It is essential that contributors observe these conventions, which may be had on request from the Editors, as the fournal now goes straight into page proof. This severely limits the number of corrections which are possible.

Page proofs will be sent, if necessary by airmail, to each contributor (or his nominee) provided that the Editors have been given an address through which he can be reached without delay. Corrections should be kept to the minimum, and should be corrections, not new material. If they are to be incorporated in the master proof corrected by the Editors, it is important that the contributor should return the page proofs, by airmail if necessary, to the Editor named when they are sent out (and not to the Cambridge University Press), within ten days of his receipt of them.

Contributors of articles and review articles receive 25 free offprints. Additional offprints may be obtained at reasonable cost, provided that they are ordered before publication on the special form sent out with the page proofs.

All contributions and books for review should be addressed to The Editors, The Yournal of African History, School of Oriental and African Studies, University of London, London, WCIE 7HP.

\title{
(Continued from back cover)
}

\section{SHORTER Notices}

Ethiopian Studies. Proceedings of the sixth international conference, Tel-Aviv, I4-17 April, 1980. Edited by Gideon Goldenberg (DonAlD CRUMmEY), 328; Traditions d'une lignée royale des Comores. By B. A. Damir, G. Boulinier and P. Ottino (M. Newirt), 329; Khoikhoi and the Founding of White South Africa. By Richard Elphick (J. B. PeIRes), 330; A Proper Degree of Terror. By Ben MacLellan (J. B. Peires), 331; West Africa's Colonial Civil Servants in the Nineteenth Century. Edited by Kwame Arhin (A. H. M. KIRK-Greene), 33 I ; La Esclavitud en Las Canarias Orientales en El Siglo XVI (Negros, Moros Y Moriscos). By Manuel Lobo Cabrera (K. N. ChaudhurI), 332; Trade and Civilisation in the Indian Ocean: An Economic History from the Rise of Islam to $175^{\circ}$. By K. N. Chaudhuri (J. F. M.), 332; The Sudan Memoirs of Carl Christian Giegler Pasha, $1873-83$. Edited by Richard Hill (Douglas H. JoHNSTON), 333 . 


\section{CONTENTS}

I Prehistory in the Upper Nile Basin

By Peter Robertshaw (British Institute in Eastern

Africa)

II Dispossession and Accumulation in the South

African Interior: The Boers and the Tlhaping of

Bethulie, I 833-6 I

By Timothy Keegan (University of the

Witwatersrand)

III Shipping Subsidies and Railway Guarantees:

William Mackinnon, Eastern Africa and the Indian

Ocean, i 860-93

By J. Forbes Munro (University of Glasgow)

IV The Role of the British Administration in the

Appointment of the Emirs of Northern Nigeria, 1901-1931: The Case of Sokoto Province

By Peter Kazenga Tibenderana (Ahmadu Bello

University, Zaria)

V The Emergence of Capitalist Relations in South

Asante Cocoa-Farming, C.1916-1933

By Gareth Austin (Institute of Commonwealth

Studies, London)

\section{Review Articles}

Sudanese and Saharan Studies

By Humphrey J. Fisher (S.O.A.S., University of London)

Americans and Africa

By ANDREw ROBERTS (S.O.A.S., University of

London)

Books Reviewed

Cambridge History of Africa, Volume 6, c. 1870-1905. Edited by Roland Oliver and G. N Sanderson (John MCCracken), 301; Cambridge History of Africa, Volume 7, 1905 to 1940. Edited by A. D. Roberts (Terence Ranger), 303; History of West Africa, Volume 1 (third edition). Edited by J. F. A. Ajavi and Michael Crowder (J. D. FAGE), 305; Red Gold of Africa: Copper in Precolonial History and Culture. By Eugenia W. Herbert (David Birmingham), 308; The History of Civilisation in North Madagascar. By Pierre Vérin. Histoire el Civilisation du Nord-Ouest Malgache. Omaly Sy Anio, nos. 17-20 (1983-84) (M. NewITt), 310; Yohn Philip (1775-1851): Missions, Race and Politics in South Africa. By Andrew Ross (Richard Gray), 312; Arab versus European, Diplomacy and War in Nineteenth Century East Central Africa. By Norman Robert Bennett (ROY Bridges), 313; The Colonisation of the Southern Tswana, I870-I900. By Kevin Shillington (NeIL. Parsons), 314; West Africa Partitioned. Volume II: The Elephants and the Grass. By John D. Hargreaves (A.S. KANYA-ForstNER), 316 ; The Rising of the Red Shawls: A Revolt in Madagascar, 1895-1899. By Stephen Ellis (Terence RanGer), 317; An African Victorian Feminist: the Life and Times of Adelaide Smith Casely Hayford, 1868-1960. By Adelaide M. Cromwell (Richard Rathbone), 320; Body of Power, Spirit of Resistance; The Culture and History of a South African People. By Jean Comaroff (Kevin Shillington), 321; The Politics of Africa's Economic Stagnation. By Richard Sandbrook. Migrant Laborers. By Sharon Stichter. Farm Labour. By Ken Swindell (Susan MarTin), 323 ; Literature and Society in South Africa. Edited by Landeg White and Tim Couzens (Richard Rathbone), 324; Guns and Rain: Guerillas and Spirit Mediums in Zimbabwe, by David Lan. Peasant Consciousness and Guerrilla War in Zimbabwe. By Terence Ranger (Hugh MacmillaN), 326. 